Dina Liović, mag.oec.

Ekonomski fakultet, Sveučilište Josipa Jurja Strossmayera u Osijeku, Osijek, Republika Hrvatska

dinali@efos.hr

doc.dr.sc. Blaženka Hadrović Zekić

Ekonomski fakultet, Sveučilište Josipa Jurja Strossmayera u Osijeku, Osijek, Republika Hrvatska

hadrovic@efos.hr

izv. prof. dr. sc. Ivana Dražić Lutilsky

Ekonomski fakultet, Sveučilište u Zagrebu, Zagreb, Republika Hrvatska idrazic@efzg.hr

\title{
OUTSOURCING RAČUNOVODSTVENE FUNKCIJE - STRATEGIJA UPRAVLJANJA TROŠKOVIMA U OKVIRU EKONOMIKE TRANSAKCIJSKIH TROŠKOVA
}

Pregledni rad

\section{Sažetak}

Ekonomiku transakcijskih troškova (engl. Transaction cost economics-TCE), interdisciplinarni pristup koji objašnjava nastanak i postojanje poduzeća, moguće je višestruko primjenjivati u poslovanju - prilikom donošenja poslovnih odluka ili u analizi upravljačke strukture odnosa kupac - dobavljač. Ovim se pristupom izučavaju ukupni troškovi poslovanja, a poseban se naglasak stavlja na troškove ugovaranja, pregovaranja i procesa upravljanja koji pruža definiciju zašto i gdje postoje granice poduzeća, čime je moguće razjasniti razloge zbog kojih neka poduzeća određene poslove izvršavaju samostalno, dok neka pak angažiraju druga - za to kompetentnija poduzeća. U tom kontekstu, ekonomiku transakcijskih troškova u poslovanju moguće je primijeniti i na outsourcing - svojevrsnu strategiju upravljanja troškovima kojom se u poslovanju koriste vanjska poduzeća i pojedinci za obavljanje pojedine poduzeću sporedne (non-core business) aktivnosti, čime se istovremeno omogućava pružanje kvalitetnijih i boljih usluga sa što manjim troškovima te se poduzeće može fokusirati na glavne (core business) aktivnosti. Funkcija poslovanja koja je predmet proučavanja u ovom radu računovodstvena je funkcija koja igra važnu ulogu u današnjem poslovanju svakog poduzeća - bez obzira na njegov oblik, veličinu i strukturu. 
Primarni cilj rada povezati je teorijski model s praksom i ukazati na mogućnosti upotrebe istog u poslovanju. Radom se daje detaljan pregled dosadašnjih otkrića $i$ rezultata dobivenih provođenjem istraživanja o outsourcingu računovodstvene funkcije, u okviru ekonomike transakcijskih troškova. U analizi postojeće literature poseban se naglasak stavlja na kontekst odrednica i čimbenika koji doprinose odluci poduzeća o primjeni outsourcinga računovodstvene funkcije te učinaka istog na uspješnost poduzé́a - primjenom ekonomike transakcijskih troškova. Navedeno se uviđa kao nužno s obzirom na nepostojanje istraživanja u navedenom kontekstu u Republici Hrvatskoj, a s druge pak strane, postojanje (još uvijek) brojnih nedoumica i kontroverza oko samog koncepta outsourcinga.

Ključne riječi: ekonomika transakcijskog troška, outsourcing, računovodstvena funkcija, računovodstveni servisi

JEL: D23, M41, M55

\section{UVOD}

Okruženje u kojem poduzeća djeluju i posluju danas, bez obzira na njihovu strukturu i veličinu, neprestano im nalaže i od njih zahtijeva nova rješenja, nove pristupe, nove strategije, nove načine poslovanja i upravljanja. Suvremeno poslovanje nalaže specijalizaciju poslovanja i eksternalizaciju, odnosno primjenu strategije outsourcinga za sporedne aktivnosti poduzeća, čime se ostvaruje velik rast transakcija među poduzećima, a samim time i transakcijskih troškova. Kao primarni cilj outsourcing ima smanjenje troškova uz istovremeno poboljšanje produktivnosti, kvalitete i efikasnosti primarne djelatnosti poduzeća (Liović, 2016., 223.). Idejni se koncept outsourcinga mijenjao tijekom vremena, a u svojim je začetcima za glavni cilj imao isključivo ostvarenje ušteda u poslovanju, a potom se razvio u koncept koji se, uz prethodno, usmjerava i teži ostvarenju veće konkurentske prednosti svih vrsta poduzeća, kao i njihove bolje pozicije na tržištu (Vučur, 2016., 284.). Konkretna funkcija poslovanja koja je predmet proučavanja u ovom radu računovodstvena je funkcija koja ima iznimnu ulogu u poslovanju svakog poduzeća. Ekonomika transakcijskih troškova (engl. Transaction cost economics, u nastavku TCE), temeljem prethodno provedenih istraživanja, razvila se u iznimno korisnu teoriju i alat za objašnjavanje zašto neka poduzeća obavljaju računovodstvene poslove unutar poduzeća, dok druga poduzeća koriste usluge outsourcinga i profesionalnog računovođe, odnosno računovodstvenog servisa - poduzeća koji može biti od iznimno velike pomoći u smanjenju transakcijskih troškova. 


\section{EKONOMIKA TRANSAKCIJSKIH TROŠKOVA - TEORIJSKI OSVRT}

Svakom je poduzeću primarni cilj biti bolji i uspješniji od ostalih na tržištu, a ostvarenje konkurentne prednosti danas je ključno u poslovanju. Ostvarena konkurentna prednost uspješna će poduzeća razlikovati od neuspješnih, koja će ujedno ostvarivati i natprosječne poslovne rezultate te biti u mogućnosti kontrolirati poslovanje, kako u sadašnjosti tako i u budućim razdobljima (Križman Pavlović i Kalanj, 2008., 64.). Ekonomika transakcijskih troškova, u literaturi poznata i pod nazivom teorija transakcijskih troškova (engl. Transaction cost theory - TCT) jedna je od značajnih teorija poduzeća koja objašnjava nastanak, postojanje te zašto i gdje postoje granice poduzeća, kao i teorija o konkurentnosti i (održivoj) konkurentskoj prednosti. TCE je teorija isključivo o poduzeću (engl. Theory of the Firm) jer je u svemu usmjerena na pitanje zašto postoje poduzeća (Dunković, 2001., 106.). Dakle, navedenom je teorijom, između ostaloga, moguće pojasniti zašto određena poduzeća određene aktivnosti izvršavaju sama (interno), dok određena pak poduzeća izvršenje nekih od svojih aktivnosti prepuštaju drugim poduzećima (eksterno).

Polazište TCE, kako i sam naziv kaže, transakcijski su troškovi koje je moguće definirati kao troškove koji nastaju indirektno u fizičkom procesu proizvodnje, pri čemu se misli na troškove informacija, pregovaranja, potpisivanja i zaključivanja ugovora, realizacije vlasničkih prava, troškove nadzora (Kolaković, Kovačević i Sisek, 2002., 939.). To su troškovi identifikacije strana s kojima se dogovara, troškovi dovođenja u vezu, troškovi pregovora i primjene ostvarenog dogovora o provedbi ugovora ili prihvaćene norme ponašanja (Mlikotin, Tomić i Šega, 2006., 369.). U slučaju kada transakcijskih troškova ne bi bilo, odnosno kada bi njihova vrijednost bila nula, ne bi postojao problem ekonomske teorije. No, transakcijski troškovi postoje, i što su veći više smanjuju opseg transakcija čime prisiljavaju poduzeća da ekonomiziraju tim troškovima. Eksternalizacija aktivnosti koje nisu primarne dovodi do velikog porasta transakcija među poduzećima, a samim time i do porasta transakcijskih troškova. Poduzeća shvaćaju kako dugoročnim ugovorima poslovnih odnosa postižu obostrane uštede u odnosu na čiste tržišne odnose, a posebice u odnosu na internalizaciju aktivnosti u poslovanju. Stoga se ekonomiziranje troškova poduzećima danas nalaže, ono je imperativ (Kolaković, Kovačević i Sisek, 2002., 950.).

Općenito, odluka o eksternalizaciji ili internacionalizaciji u određenoj situaciji ovisi o komparativnim troškovima transakcije, tj. troškovima izvršenja usluge, uključujući ex-ante troškove pregovaranja o ugovoru, i ex-post troškove praćenja performansi i pružanja povratnih informacija (Everaert, Sarens i Rommel, 2010.). U slučaju kada su troškovi transakcija na tržištu manji od troškova istih transakcija unutar poduzeća, tada će biti izabrana tržišna alokacija, dok će suprotno doći 
do organizacije transakcija unutar poduzeća čime se objašnjava nastanak i postojanje poduzeća (Kolaković, Kovačević i Sisek, 2002., 939.). Izvorni su autori ove teorije nobelovci Ronald H. Coase i njegov sljedbenik Oliver E. Williamson. U svom ključnom radu Narav poduzeća (engl. The Nature of the Firm) temelje ovoj teoriji još 1937. godine postavio je Coase, koju je kasnije nadopunio i objedinio autor Williamson (1979., 1989., 1998.). S obzirom na razdoblja u kojima su navedeni autori proučavali TCE teoriju te postavili njene temelje, očigledna je njena dugogodišnja tradicija koju noviji autori redefiniraju i prilagođavaju tržištu u sadašnjem vremenu, znatno drugačijem u odnosu na prošlo stoljeće. Coase izjednačava poduzeća i tržište kao alternativne organizacijske oblike za upravljanje istim transakcijama, i ističe kako će izbor mjesta izvršenja transakcije utjecati na učinkovitost. Poduzetnici odlučuju gdje će se transakcije izvršiti - unutar poduzeća ili na tržištu, ovisno o vrsti i veličini troškova (Neves, Hamacher i Scavarda, 2014., 687.). Prema Coaseu, poduzeća postoje kao ekonomski entiteti samo zato što postoje transakcijski ili marketing troškovi koje one mogu svesti na minimum. Kada bi ti troškovi bili jednaki onima koji bi nastali korištenjem tržišta, tada poduzeća ne bi postojala (Dunković, 2001., 107.). Prema Williamsonu, TCE teorija predstavlja interdisciplinarni pristup koji sjedinjuje pravo, ekonomiku i organizacijsku teoriju (Kolaković, Kovačević i Sisek, 2002., 939.). Proširivši istraživanja Coasea, on navodi dva čimbenika koji mogu dovesti do transakcijskih troškova. Prvi se odnosi na ograničenu racionalnost, nesposobnost ljudi u predviđanju svih čimbenika koji se odnose na transakciju (Neves, Hamacher i Scavarda, 2014., 688.) čime se ukazuje na ograničenja spoznajnih mogućnosti ljudi i u racionalnosti ponašanja, što daje posebnu ulogu tržištu i objašnjava zbog čega planiranje ne može biti isključivi alokativni mehanizam (Kolaković, Kovačević i Sisek, 2002., 939.). Drugi je čimbenik rizik od oportunizma do kojeg dolazi kada jedna strana koja sudjeluje u transakciji ostvaruje koristi od nepredviđenih promjena uvjeta vezanih za transakciju (promjene u kvaliteti, tehnologiji i tržišnim uvjetima ponude i potražnje), a uzevši u obzir tu situaciju, jača strana u transakciji zahtijeva izmjene ugovora kojima ostvaruje neopravdanu prednost (Neves, Hamacher i Scavarda, 2014., 689.). Oportunizam dakle ukazuje na sebično zadovoljavanje vlastitih interesa čime se objašnjavaju prijevare, lukavstva i slučajevi davanja selektivnih ili netočnih informacija (Kolaković, Kovačević i Sisek, 2002., 939.). Moguća je uporaba TCE teorije pri donošenju poslovne odluke po načelu ,proizvesti ili nabaviti“ (engl. make-or-buy) ili u analizi upravljačke strukture odnosa kupac - dobavljač (Križman Pavlović i Kalanj, 2008., 66.). Analizirajući TCE iz perspektive odluke po načelu ,proizvesti ili nabaviti”, gdje se odabire između proizvodnje proizvoda unutar poduzeća ili kupnje od vanjskog dobavljača, teorija predviđa da će menadžeri provesti organizacijski oblik koji umanjuje troškove transakcije (Neves, Hamacher i Scavarda, 2014., 689.). Williamson je Coasevoj teoriji dodao ključne dimenzije sukladno kojima se transakcije razlikuju i koje utječu na transakcijske troškove. To su: stupanj i tip neizvjesnosti s kojim se transakcije suočavaju (engl. uncertainty - teškoća predviđanja svih situacija koje 
se mogu dogoditi tijekom transakcije), učestalost provedbe transakcije (engl. frequency of trading) i posebnost, odnosno specifičnost dobra (engl. asset specificity - stupanj specifičnosti dobra koje je predmet transakcije) (Neves, Hamacher i Scavarda, 2014., 689.). Posljednjoj od navedenih dimenzija iznimno je teško pronaći jedinstveno odgovarajući prijevod, s obzirom da se u većini literature ona smatra dobrom u ekonomskom smislu, odnosno objektom transakcije u najširem mogućem značenju, a ne isključivo fizičkom dobru. U slučaju kada je imovina specifična, neizvjesnost na niskoj razini, a transakcije se provode relativno često, transakcijama bi trebalo upravljati tržište te se tada ne bi trebali razviti dugoročni odnosi s dobavljačima. Suprotno, niska posebnost dobra/imovine i neizvjesnost rezultiraju transakcijskim poteškoćama i hijerarhijskom upravljanju. TCE kao temeljnu pretpostavku ima odabir načina upravljanja od strane poduzeća sukladno djelotvornosti u kontekstu troškova u konačnici i oportunističkog rizika (Križman Pavlović i Kalanj, 2008., 66.). Najvažnijom dimenzijom, od triju navedenih, navodi se posebnost imovine (dobra), koju nije moguće upotrijebiti u druge svrhe bez gubitaka ili nije upotrjebljiva uopće (Kolaković, Kovačević i Sisek, 2002., 940.). Posebnost, odnosno specifičnost imovine (dobra) najvažniji je aspekt transakcije te se pod time misli na specifičnost imovine u fizičkom smislu, kao i na specifičnost ljudskog kapitala. Imovina - roba i usluge visoke specifičnosti ne mogu se koristiti u drugim transakcijama bez enormno velikih dodatnih troškova (Arnold, 2000., 25.). Za upravljanje imovinom niske specifičnosti moguće je upotrijebiti outsourcing. Niska specifičnost znači da mali broj informacija mora biti razmijenjen s vanjskim partnerom. Suprotno, mnogo informacija treba razmjenjivati prije, tijekom i nakon razmjene dobara i usluga visoke specifičnosti, što rezultira izuzetno visokim transakcijskim troškovima (Arnold, 2000., 25.). TCE teorijom sugerira se uspostava transakcijskih odnosa s dobavljačem u slučajevima niskog stupnja neizvjesnosti realizacije i velikog obujma transakcije. Partnerski odnos s dobavljačem preporuča se u situaciji visokog stupnja neizvjesnosti transakcije i niskog obujma. Poduzeća su u mogućnosti poboljšati svoju konkurentnost i čak ostvariti konkurentsku prednost ulažući vlastite resurse i sposobnosti u izgradnju i održavanje specifičnih dugoročnih odnosa s primarnim dionicima, posebice kupcima i dobavljačima te posrednicima i zaposlenicima (Križman Pavlović i Kalanj, 2008., 67.). Što je specifičnija imovina (dobro), veća je prijetnja oportunizma i neizvjesnost, a također i vjerojatnost obavljanja takve transakcije unutar poduzeća. Utjecaj transakcijskih troškova na poduzeće ili tržišnu alokaciju time dobiva svoju potvrdu i na taj se način minimizacija transakcijskih troškova pokazuje kao osnova za postojanje poduzeća (Kolaković, Kovačević i Sisek, 2002., 940.). U skladu s tipičnom definicijom poduzeća, koja počiva na stavovima TCE torije, poduzeće je poseban skup ugovora koji uključuju pravo raspolaganja nad privatnim vlasništvom, to je fizički skup resursa čiji je međuodnos predmet ugovora. O strukturi i svrsi poduzeća ovisi hoće li će taj ugovor biti između poslodavca i zaposlenika, između dobavljača i kupca, između poslodavca i vlade (Dunković, 2011., 111.). 


\section{POJMOVNO DEFINIRANJE I PRIMJENA OUTSOURCINGA U RAČUNOVODSTVU}

Kao pristup i koncept poslovanja, outsourcing nije novina i moderna poslovna strategija, već je prisutan (pod drugim nazivima) od rane povijesti te se može reći kako outsourcing zapravo postoji onoliko dugo koliko postoji i sama trgovina (Liović, 2016., 224., prema: Anadachee, 2012., 37.). Outsourcing je dakle strategija koja se prakticira već tisućljećima, a njegova primjena u poslovanju, u sadašnjem obliku kao jedne od poslovnih strategija, započela je za vrijeme Drugog svjetskog rata (Liović, 2016., 224., prema: Espiritu, 2008., 20.). Tijekom prethodnih dvadesetak godina outsourcing poprima veliki značaj i postaje popularna inicijativa za strateško upravljanje. Unazad navedenog razdoblja, dolazi do povećanja ekonomske vrijednosti, strateške važnosti i složenosti outsourcinga, čiji je razvojni put krenuo od rutinskih i nerutinskih aktivnosti, kao što su primjerice osiguranje, zaštita, usluge čišćenja i održavanja, ugostiteljstva, do ključnih funkcija podrške poslovanju kao što su logistika, računovodstvo, informacijske tehnologije te sve do ključnih proizvodnih funkcija kao što su dizajn i određeni proizvodni procesi (McCarthy i Anagnostou, 2004., 63.). Bahtijarević-Šiber i Sikavica (2001., 102.) navode kako se prilikom outsourcinga poduzeća orijentiraju na svoj glavni posao (core business), a ostale poslove, u kojima su slabiji od konkurencije, eksternaliziraju. Orijentacija poduzeća na core business i outsourcing uzajamno su uvjetovane strategije. Dakle, poduzeće koje se odluči na takav način poslovanja u potpunosti je omogućeno usmjeriti se i posvetiti za njega ključnim poslovnim procesima i aktivnostima, dok one manje bitne, odnosno aktivnosti u kojima je poduzeće manje kompetentno i specijalizirano povjerava vanjskom poduzeću koje će navedeno obaviti efikasnije, kvalitetnije i jeftinije. To u konačnici poduzeću donosi i značajne uštede, kako u pogledu novca, tako i vremena. Outsourcing se najjednostavnije smatra sporazumom u kojem jedno poduzeće dio svojih postojećih internih aktivnosti, odnosno poslova ,izdvaja“ iz poduzeća i njihovo obavljanje prepušta drugom poduzeću, odgovarajućem i specijaliziranom za navedene aktivnosti (McCarthy i Anagnostou, 2004., 63.). Ono što se naglašava kao ključno obilježje outsourcinga jest mogućnost koncentriranja poduzeća na njegove osnovne kompetencije i aktivnosti, prenošenjem nekih, poduzeću manje bitnih poslova kooperantima (Liović, 2016., 224., prema: Anadachee, 2012., 38.). Usluge outsourcinga danas je moguće koristiti u popriličnom velikom broju poslovnih procesa i funkcija, odnosno može se reći i u svima, no poslovna funkcija na koju se primarno usmjerava ovaj rad jest računovodstvena. Sukladno dosadašnjim istraživanjima, outsourcing u kontekstu računovodstva definitivno je manje zastupljen i u znatno manjoj se mjeri primjenjuje u odnosu na primjerice IT outsourcing. Navedeno je moguće zaključiti prema opsegu, dubini i općenito provedbi dosadašnjih istraživanja u segmentu outsourcinga računovodstvene funkcije, u odnosu prema IT outsourcingu (Liović, 2016., 225., 
prema: Hayes, 1999., 7.). Unatoč navedenom, dolazi do promjene trenda i poduzeća se sve više odlučuju na angažiranje vanjskih poduzeća koja su se specijalizirala u pružanju potrebnih računovodstvenih usluga. Računovodstvo je disciplina neprestano suočena s mnoštvom različitih regulativa, propisa, stalnim izmjenama i dopunama zakona i pravilnika. Kao visoko regulirana profesija, računovodstvo je i disciplina koja ima utjecaj na javni interes, jer su računovodstvene usluge korištene od strane raznih interesnih skupina. Samim time, računovodstveni je posao iznimno kompleksan i zahtjevan, i ukoliko se poduzeće primarno ne bavi računovodstvom i ne posjeduje kadar dorastao poslu računovođe, lako dolazi do problema prilikom objedinjavanja svih mogućih poslova koji se zahtijevaju od njega. Sve karakteristike outsourcinga primjenjive su i na računovodstvenu funkciju kada ono nije primarna aktivnost poduzeću, jer je u suštini funkcija koja ima iznimno važnu ulogu i iznimno je važan dio ukupnog poslovanja, bez obzira kojeg je oblika i veličine poduzeće. Stoga, nužno je da poduzeća budu svjesna važnosti računovodstva i svih koristi računovodstvenih informacija zbog mogućnosti bolje kontrole upravljanja i donošenja odluka kako bi mogli pristupiti novim tržištima i povećati svoju dobit u korporativnom svijetu (Liović, 2016., 225., prema: Jayabalan et al., 2009., 112.). Ukoliko se primarno i ne bavi računovodstvom, poduzeće ne može zanemariti računovodstvenu funkciju te ju u tim slučajevima treba prepustiti specijaliziranim poduzećima. Pod tim specijaliziranim poduzećima prvenstveno se smatraju računovodstveni servisi kojima je pak primarna funkcija upravo računovodstvena i koji svakom poduzeću, pružanjem svojih usluga, mogu pomoći u obavljanju računovodstvenih aktivnosti, za što su specijalizirani. Bez računovodstva - točnih pokazatelja o poslovanju, brzo dostupnih i provjerenih podataka, dobro vođene porezne politike, kvalitetnih izvještaja i točnih podataka, poduzeće nije u mogućnosti donositi prave poslovne odluke. Upravo u tom su segmentu računovodstveni servisi ključni jer navedeni nedostatak poduzeća uočavaju i ističu kao svoju glavnu prednost. Pod outsourcingom računovodstva podrazumijeva se prijenos cijele ili dijela računovodstvene funkcije vanjskom (profesionalnom) računovođi s namjerom i ciljem smanjenja troškova, dobivanja pristupa oskudnim vještinama i ostvarivanja konkurentske prednosti. Uobičajeni primjeri outsourcinga računovodstva jesu knjigovodstvo, upravljanje riznicom i novcem, obračun plaća, obveza prema dobavljačima, obrada računa i ostali specifični procesi (Hamzah et al., 2010., 3308.). Računovodstveni servisi poduzeću mogu pružiti računovodstvene usluge poput izrade mjesečnih, kvartalnih i godišnjih izvješća, usklađivanja zakonskih i internih izvješća poduzeća, prikupljanja i dostave knjigovodstvene dokumentacije te predaje iste Poreznoj upravi, HZZO-u, Mirovinskom fondu, bankama itd. Temeljem naprednih alata za kreiranje izvještaja, računovodstveni servisi pružaju detaljan uvid u poslovanje, i sve što obavljaju u skladu je s računovodstvenim zakonima i propisima te standardima financijskog izvještavanja i računovodstvenim politikama (Liović, 2016., 226.). 


\section{ISKUSTVA PRIMJENE OUTSOURCINGA U REPUBLICI HRVATSKOJ}

Promatra li se stanje i situacija u Republici Hrvatskoj (u nastavku RH) po pitanju outsourcinga, specifičnost i konfuzija kreće od samog početka - njegova naziva. S obzirom na strano podrijetlo, nazivu outsourcing pokušao se naći odgovarajući prijevod - izraz koji bi u potpunosti označavao sve što outsourcing jest. Time je u RH došlo do konfuzije s obzirom da su kao prikladni prijevodi u upotrebi i izrazi koji ne označavaju u potpunosti pravu bit outsourcinga. Među brojnim dostupnim nazivima, odgovarajući izraz koji se primjenjuje u istom kontekstu i značenju kao outsourcing jest eksternalizacija, no zbog svoje prepoznatljivosti i ukorijenjenosti u poslovnu praksu i jezik u RH, kao i zastupljenosti istog u stranoj literaturi, u radu će primarno biti korišten izvorni pojam outsourcing. S obzirom da, teorijski gledano, odluka o primjeni outsourcinga - uključivanje vanjskih partnera u poslovanje poduzeća treba rezultirati smanjenjem određenih vrsta troškova (ovisno o vrsti poduzeća) te u konačnici dovesti do povećanja dobiti poduzeća, može se zaključiti kako outsourcing ispunjava svoj primarni cilj i zadatak te opravdava naziv dobre poslovne strategije. Upravo navedeno temeljni je motiv i polazište ovome radu, kao i općenito proučavanju navedene tematike. Računovodstvena funkcija poslovanja, u kontekstu outsourcinga koristi se i primjenjuje u znatno manjoj mjeri u poslovanju poduzeća u RH, no bitno je naglasiti kako je u posljednje vrijeme vidljiv trend rasta te se sve više poduzeća odlučuje na primjenu outsourcinga u poslovanju. Kao pružatelji usluga outsourcinga računovodstva, iako se isti smatra novijim konceptom poslovanja, primarno se podrazumijevaju računovodstveni servisi koji postoje i posluju već dugi niz godina u RH što znači da zapravo toliko dugo postoji i sama praksa outsourcinga računovodstvene funkcije na tržištu RH. No, pitanje koje se potom postavlja jest ukoliko ta praksa u RH postoji, zašto su prisutne kontroverze oko outsourcinga u javnosti i postoje li i koji su „opipljivi“" rezultati primjene istog u području računovodstva u poslovanju? Dostupna literatura i provedena istraživanja u RH na temu outsourcinga općenito (detaljan prikaz slijedi u nastavku rada) pokazuju kako je navedeno područje još uvijek nedovoljno istraženo i nepoznato, i ista je situacija, čak i znatno nepovoljnija po pitanju istraživanja primjene outsourcinga računovodstvene funkcije s obzirom da su u RH istraživanja outsourcinga u području računovodstva provedena samo za potrebe diplomskih i magistarskih radova te od strane poduzeća koja navedene usluge pružaju. Istraživanja provedena u RH na temu outsourcinga odnose se na utvrđivanje razine upotrebe outsourcinga u poslovanju poduzeća, kao i u kojoj se mjeri outsourcing koristi za određene poslovne funkcije. Unatoč važnosti i značajnosti računovodstva za poslovanje poduzeća u cjelini, nedostatan je broj znanstvenih radova koji proučava temu outsourcinga računovodstva u RH. No, gledajući cjelokupno tržište $\mathrm{RH}$, može se reći kako je ono u porastu kada je riječ o broju specijaliziranih pružatelja usluga outsourcinga, a potražnja za outsourcing 
uslugama zabilježena je u području računovodstvenih usluga, IT usluga, ugostiteljskih usluga, usluga čišćenja i prostora za održavanje (Dražić Lutilsky, Dragija i Krnjić, 2015., 288.). Navedenim se ukazuje na mogućnost i potrebu provedbe istraživanja u RH i na temu rada, s obzirom na potražnju koja za istim postoji na tržištu, dok postojanje istraživanja i radova iz područja IT outsourcinga ukazuje na aktualnost, kao i poznavanje koncepta outsourcinga na području RH.

U nastavku rada daje se sumirani prikaz rezultata i zaključaka empirijskih istraživanja provedenih u RH na temu outsourcinga.

Tablica 1. Pregled empirijskih istraživanja primjene outsourcinga u poslovanju poduzeća u Republici Hrvatskoj

\begin{tabular}{|c|c|}
\hline Autor(i) & Rezultati i zaključci istraživanja \\
\hline $\begin{array}{c}\text { Parlov, I. } \\
\text { (2004) }\end{array}$ & $\begin{array}{l}73 \% \text { ispitanika (uzorak } 91 \text { veliko poduzeće) primjenjuje outsour- } \\
\text { cing; } 68 \% \text { smatra kako outsourcing nema ili ima mali utjecaj na } \\
\text { ostvarivanje ciljeva poduzeća; velika većina ispitanih tvrtki je ma- } \\
\text { nje ili više zadovoljna outsourcingom ( } 70 \% \text { ), a vrlo mali broj njih } \\
\text { je nezadovoljno - prvi pokazatelj outsourcinga kao korisnog alata } \\
\text { upravljanja. }\end{array}$ \\
\hline $\begin{array}{c}\text { Pavić, M. } \\
\text { (2009) }\end{array}$ & $\begin{array}{l}71,88 \% \text { ispitanika (uzorak } 32 \text { velika poduzeća) primjenjuje out- } \\
\text { sourcing; pojava negativnih efekata primjene outsourcinga kod } \\
43,48 \% \text { anketiranih poduzeća (sporije rješavanje problema uzroko- } \\
\text { vano gubitkom kontrole, pojava nepredviđenih troškova i upitnost } \\
\text { kvalitete outsourcing aktivnosti, blagi oblik pojave monopola po- } \\
\text { jedinih outsourcing poduzeća); zbog zastarjelosti tehnologije ne- } \\
\text { mogućnost konkuriranja hrvatskih poduzeća na globalnom tržištu. }\end{array}$ \\
\hline $\begin{array}{c}\text { Šarić, M. } \\
(2011)\end{array}$ & $\begin{array}{l}\text { Većina velikih poduzeća u RH primjenjuje outsourcing za manje } \\
\text { bitne poslovne zadatke (ovisno o glavnoj djelatnosti poduzeća) i s } \\
\text { ciljem smanjenja troškova poslovanja.; aktivnosti koje se najčešće } \\
\text { izdvajaju su transport i distribucija, IT i čišćenje/održavanje; potre- } \\
\text { be za uslugama outsourcinga u RH rastu; zapreke za razvoj u RH } \\
\text { - nespremnost i nezrelost domaćeg tržišta za individualne davatelje } \\
\text { outsourcinga i nezainteresiranost velikih međunarodnih subjekata } \\
\text { za hrvatsko tržište, radnički i službenički sindikati; u aktivnostima } \\
\text { u informatičkom sektoru postoje problemi oko zaštite podataka. }\end{array}$ \\
\hline $\begin{array}{c}\text { Brkić, A. } \\
\text { (2013) }\end{array}$ & $\begin{array}{l}\text { Uzorak } 26 \text { poduzeća svih veličina u RH (11 poduzeća koja poslu- } \\
\text { ju samo u RH, } 10 \text { poduzeća koja posluju u EU i } 5 \text { poduzeća koja } \\
\text { posluju diljem svijeta); upotreba outsourcinga s ciljem smanjenja } \\
\text { troškova poslovanja, bolje kvalitete proizvoda, povećanja kon- } \\
\text { kurentnosti, širenja na globalno tržište; zbog nedostatka stručnih } \\
\text { zaposlenika; najčešće se koristi IT outsourcing, zatim outsourcing } \\
\text { ljudskih resursa, računovodstva i transporta. Većina ispitanih me- } \\
\text { nadžera smatra kako je vrlo dobro upoznato s pojmom outsourcin- } \\
\text { ga (pozitivna činjenica za budućnost outsourcinga u RH), veličina } \\
\text { poduzeća utječe na primjenu outsourcinga. }\end{array}$ \\
\hline
\end{tabular}




\begin{tabular}{|c|c|}
\hline $\begin{array}{c}\text { Krnjić, A. } \\
\text { (2014) }\end{array}$ & $\begin{array}{l}\text { Od } 29 \text { ispitanih poduzeća - } 14 \text { radi inozemno, a samo } 10 \text { isključi- } \\
\text { vo na području RH. Rezultati: većina ispitanih hrvatskih poduze- } \\
\text { ća primjenjuje outsourcing, a menadžeri tih poduzeća outsourcing } \\
\text { uzimaju u obzir kao učinkovit način poslovanja; razvija se svijest o } \\
\text { outsourcingu; hrvatska poduzeća su upoznata s konceptom outso- } \\
\text { urcinga, shvaćaju prednosti i nedostatke istog. }\end{array}$ \\
\hline $\begin{array}{l}\text { Cronata d.o.o. i } \\
\text { BNB Sklad d.o.o. } \\
\\
(2016)\end{array}$ & $\begin{array}{l}\text { Hrvatska poduzeća sve više prepoznaju prednosti outsourcinga, a } \\
\text { najčešće koriste vanjske usluge čišćenja i održavanja }(61,7 \%) ; 91 \% \\
\text { ispitanika (uzorak od } 60 \text { poduzeća, <6-50 zaposlenih ili }>250 \text { za- } \\
\text { poslenih) smatra outsourcing poželjnim; najveća prednost je fokus } \\
\text { na osnovnu djelatnost.; istraživanje ukazuje na razvoj tržišta i pri- } \\
\text { hvaćanje svjetskih trendova; 55\% hrvatskih poduzeća namjerava } \\
\text { više koristiti outsourcing; ključni razlozi koji sprječavaju primjenu } \\
\text { outsourcinga: manjak vremena i volje te slab izbor poduzeća koje } \\
\text { nude željenu uslugu - slabo poznavanje što se sve od usluga za } \\
\text { outsourcing i koliko kvalitetno danas nudi, al istovremeno i potvrda } \\
\text { kako je outsourcing nedovoljno razvijen i primjenjen u RH velikim } \\
\text { dijelom zbog nedovoljno saznanja o istome. }\end{array}$ \\
\hline $\begin{array}{c}\text { Vučur, G. } \\
\text { (2016) }\end{array}$ & $\begin{array}{l}\text { U hotelskim poduzećima (uzorak } 313 \text { hotelskih poduzeća svih veli- } \\
\text { čina) povećanje razine outsourcinga povećava i razinu profitabilno- } \\
\text { sti; između povećanja razine outsourcinga i povećanja neto profitne } \\
\text { marže te povrata na ukupnu imovinu u velikim hotelskim poduze- } \\
\text { ćima postoji jaka, statistički značajna i pozitivna veza; povećanje } \\
\text { razine outsourcinga aktivnosti poslovanja ima pozitivan utjecaj na } \\
\text { dobit velikih hotelskih poduzeća koja može proizlaziti iz smanjenja } \\
\text { troškova poslovanja u odnosu prema ostvarenoj prodaji. }\end{array}$ \\
\hline
\end{tabular}

Izvor: Sistematizacija i izrada autora

\section{MOGUĆNOSTI PRIMJENE EKONOMIKE TRANSAKCIJSKIH TROŠKOVA U OUTSOURCINGU RAČUNOVODSTVENE FUNKCIJE}

Istraživanjima o outsourcingu nužno se posvetiti prvenstveno kako bi se upoznalo s problemima s kojima se suočavaju poduzeća prilikom korištenja ili namjere korištenja outsourcinga. Također, navedenu je tematiku nužno istraživati kako bi se poduzećima mogle dati određene preporuke i savjeti pri eventualnim nedoumicama u začetcima primjene outsourcinga, ili pak onima koji ga već primjenjuju ukazati na mogućnosti poboljšanja i unaprjeđenja koncepta outsourcinga i u konačnici poslovanja. U poduzeću gdje su računovođe interni zaposlenici, vlasnici/ menadžeri s punim se povjerenjem oslanjaju na njihovo znanje i kompetencije u rješavanju svih nužnih računovodstvenih aktivnosti. Logično je pretpostaviti kako se navedeno znanje i kompetencije, kao i aspekt povjerenja u „svog“ računovođu pritom ne dovode u pitanje. No, prilikom outsourcinga, za provedbu vlastitog posla, vlasnici/menadžeri se moraju osloniti na znanje i kompetencije pojedinaca računovođa iz vanjskog poduzeća. Kako bi taj odnos između primatelja i pružatelja outsourcing usluge bio učinkovit, treba isključivo biti utemeljen 
na partnerskom odnosu tih poduzeća (Liović, 2016., 225., prema: Anadachee, 2012., 1.). U RH, Zakonom o računovodstvu (2015.) poduzeća se klasificiraju u četiri kategorije: mikro poduzetnici čiji je prosječan broj radnika tijekom poslovne godine do 10 , kod malih je poduzetnika taj broj je do 50, srednji su poduzetnici svi oni čiji je prosječan broj radnika do 250 te u konačnici veliki poduzetnici imaju prosječan broj radnika tijekom poslovne godine veći od 250. Sukladno tim kategorijama, nužno je prvotno utvrditi koja su poduzeća generalno, a također i u RH podobna koristiti outsourcing u poslovanju. Poduzeća se, ukoliko nemaju drugog izbora, kao primjerice mikro poduzeća čiji je broj zaposlenih premalen da bi oformili svoj interni računovodstveni odjel, neće previše dvoumiti oko odluke o primjeni outsourcinga. S druge strane, za pretpostaviti je kako velikim poduzećima nije isplativo primjenjivati outsourcing u području računovodstva jer sukladno kategoriji poduzeća, obujmu posla i broju zaposlenih već imaju zaposlenog računovođu, odnosno vjerojatnije cijeli računovodstveni odjel. No, nije isključeno da se i poduzeća koja već imaju svoj računovodstveni odjel i koji računovodstvene usluge obavljaju interno, usporedbom sadašnjeg poslovanja - ušteda i dobiti, mogu odlučiti na angažiranje vanjskog poduzeća za računovodstvene aktivnosti, ukoliko utvrde kako bi im taj način poslovanja bio efikasniji. Uvažavajući prethodno navedene pretpostavke o poduzećima kandidatima za primjenu outsourcinga, u RH bi to bila mala i srednja poduzeća. Naravno, navedeno je također pretpostavka koju je nužno istražiti i provjeriti, no uzorak je to koji se i u inozemnim istraživanjima pokazao kao ključan i odgovarajući te većina stranih autora provodi istraživanje o učincima outsourcinga na upravo navedenim poduzećima, u različitim zemljama, no s istom/sličnom klasifikacijom poduzeća kao što je u RH. Ključno pitanje koje se postavlja i što je zapravo i cilj rada jest analizirati na koji način utječu određeni vanjski čimbenici na primjenu outsourcinga u poslovanju, odnosno na razinu do koje se određene računovodstvene aktivnosti izvršavaju izvan poduzeća i postoji li i kakva je povezanost navedenog, te kakav je utjecaj primjene outsourcinga na uspješnost poduzeća. U davanju odgovora na postavljeno, moguće je upotrijebiti TCE teoriju, koja identificira ključne dimenzije, odnosno čimbenike koji utječu na razinu upotrebe outsourcinga, kao i utjecaj outsourcinga na uspješnost poduzeća u okvirima TCE teorije.

Primjenjujući TCE teoriju, brojni su autori došli do zaključaka o utjecaju različitih čimbenika na odluku o primjeni outsourcinga, kao i njegovim učincima na uspješnost poslovanja (Arnold, 2000.; Gilley i Rasheed, 2000.; Everaert, Sarens i Rommel, 2006.; 2010.; McIvor, 2009.; Kamyabi i Devi, 2011.; Kamyabi, 2012.; Hafeez i Andersen, 2014.; Neves, Hamacher i Scavarda, 2014. i drugi), i time ukazali na mogućnost upotrebe TCE teorije u kontekstu outsourcinga računovodstva. Tablicom u nastavku prikazuju se rezultati ključnih istraživanja za promatranu temu rada, nakon čega slijedi analiza mogućnosti primjene outsourcinga računovodstva u okviru TCE teorije s prikazom zaključaka do kojih je primjenom navedenog moguće doći. 
Tablica 2. Pregled empirijskih istraživanja primjene TCE teorije u definiranju odrednica outsourcinga računovodstva i utjecaj outsourcinga na uspješnost (profitabilnost) malih i srednjih poduzeća

\begin{tabular}{|c|c|}
\hline Autor(i) & Rezultati i zaključci istraživanja \\
\hline $\begin{array}{c}\text { Everaert, P., Sarens, G., } \\
\text { \& Rommel, J. } \\
(2006,2010)\end{array}$ & $\begin{array}{l}\text { Na uzorku od } 126 \text { MSP u Belgiji, autori zaključuju kako su } \\
\text { deficit potrebnih resursa, posebnost imovine i učestalost tran- } \\
\text { sakcija najznačajniji razlozi outsourcinga računovodstva; } \\
\text { stupanj obrazovanja vlasnika/menadžera igra važnu ulogu, } \\
\text { kao i prisutnost računovodstvene funkcije unutar poduzeća } \\
\text { (2006). Potvrđuju se } 2 \text { pretpostavke TCE teorije - učestalost i } \\
\text { posebnost imovine značajno su povezane varijable s stupnjem } \\
\text { primjene outsourcinga računovodstva, a uloga stupnja obra- } \\
\text { zovanja vlasnika/menadžera i povjerenja u pružatelja računo- } \\
\text { vodstvenih usluga jest ključna (2010). }\end{array}$ \\
\hline $\begin{array}{l}\text { Kamyabi, Y., } \\
\text { \& Devi, S. } \\
(2011 \mathrm{a}-\mathrm{f})\end{array}$ & $\begin{array}{l}\text { Istraživanje na } 658 \text { iranskih MSP rezultiralo je zaključcima } \\
\text { da su posebnost imovine, povjerenje i stupanj konkurencije } \\
\text { ključni čimbenici koji utječu na odluku o outsourcingu. Stu- } \\
\text { panj primjene outsourcinga značajno i pozitivno je povezan } \\
\text { s uspješnošću MSP, outsourcing posreduje u potpunosti od- } \\
\text { nos između povjerenja i uspješnosti poduzeća i djelomično u } \\
\text { odnosu između stupnja konkurencije i uspješnosti tvrtke, ali } \\
\text { ne posreduje u odnosu između specifičnosti imovine i uspješ- } \\
\text { nosti tvrtke (2011a); potvrda tri TCE pretpostavke: posebnost } \\
\text { imovine, učestalost i povjerenje u računovođe značajno su } \\
\text { povezani s outsourcingom računovodstva, dok neizvjesnost } \\
\text { okoline i ponašanja nisu značajno povezani (2011b); stu- } \\
\text { panj primjene outsourcinga pozitivno je i značajno povezan } \\
\text { s povjerenjem u vanjske računovođe, stupnjem konkurencije } \\
\text { i korporativnom strategijom; uključivanjem kontrolnih varija- } \\
\text { bli - veličina i starost poduzeća, obrazovanje i iskustvo vlasni- } \\
\text { ka/menadžera povezanost ostaje statistički značajna (2011c); } \\
\text { outsourcing računovodstva pozitivno je povezan s kompeten- } \\
\text { cijama vlasnika/menadžera i percepcijom kompetencija pru- } \\
\text { žatelja računovodstvenih usluga, ali nije pronađen pozitivan } \\
\text { odnos između outsourcinga i veličine poduzeća; outsourcing } \\
\text { ima pozitivan utjecaj na uspješnost MSP-a (2011d); posebnost } \\
\text { imovine, neizvjesnost ponašanja, stupanj povjerenja i percep- } \\
\text { cija kompetencija pružatelja outsourcing usluga te stupanj } \\
\text { konkurencije značajno su povezani s outsourcingom računo- } \\
\text { vodstvenih usluga; rezultati ukazuju pružateljima outsourcing } \\
\text { usluga na potrebno proširenje usluga MSP-ima te unaprjeđe- } \\
\text { nje vještina, znanja i stručnosti (2011e); primjena outsourcin- } \\
\text { ga računovodstvenih usluga pozitivno je povezana sa znanjem } \\
\text { i kompetencijama vlasnika/menadžera, kao i percepcijom } \\
\text { kompetencija računovodstvenih ureda, stupnjem konkurenci- } \\
\text { je te složenosti tržišnih odluka; upotreba savjetodavnih usluga } \\
\text { računovodstvenih ureda ima pozitivan učinak na uspješnost } \\
\text { MSP-a (2011f). }\end{array}$ \\
\hline
\end{tabular}




\begin{tabular}{|c|c|}
\hline $\begin{array}{c}\text { Kamyabi, Y. } \\
\text { (2012) }\end{array}$ & $\begin{array}{l}\text { Na uzorku od } 658 \text { MSP u Iranu autor zaključuje kako su čim- } \\
\text { benici - posebnost imovine, učestalost, povjerenje, kompeten- } \\
\text { cije računovodstvenog ureda i stupanj konkurencije značajno } \\
\text { povezani sa stupnjem primjene outsourcinga računovodstve- } \\
\text { nih usluga. TCE teorija pokazala se kao korisna u provedbi } \\
\text { istraživanja o outsourcingu računovodstvenih usluga u kon- } \\
\text { tekstu MSP zemalja u razvoju; rezultati sugeriraju kako je } \\
\text { stupanj primjene outsourcinga značajno pozitivno povezan s } \\
\text { uspješnošću MSP. }\end{array}$ \\
\hline $\begin{array}{c}\text { Hafeez, A., } \\
\text { \& Andersen, O. } \\
\text { (2014) }\end{array}$ & $\begin{array}{l}\text { Istraživanje provedeno na } 302 \text { MSP u Pakistanu pokazalo je } \\
\text { kako čimbenici učestalost nerutinskih aktivnosti, posebnost } \\
\text { imovine, oportunizam, povjerenje u pružatelje računovod- } \\
\text { stvenih usluga i stupanj konkurencije imaju značajan utjecaj } \\
\text { na outsourcing računovodstva. Uključivanjem kontrolnih } \\
\text { varijabli u regresijsku jednadžbu (spol, stupanj obrazovanja, } \\
\text { iskustvo, veličina i starost poduzeća) odnos između varijabli i } \\
\text { stupnja primjene outsourcinga računovodstva ostaje statistički } \\
\text { značajan. Rezultati ukazuju kako bi resurno ograničena MSP } \\
\text { trebala ,prebaciti“ svoje interno računovodstvo u vanjsko, od- } \\
\text { nosno započeti s primjenom outsourcinga. }\end{array}$ \\
\hline $\begin{array}{c}\text { Gilley, K. M., \& Ras- } \\
\text { heed, A. } \\
(2000)\end{array}$ & $\begin{array}{l}\text { Autori na uzorku od } 94 \text { velika poduzeća ne otkrivaju izravno } \\
\text { djelovanje outsourcinga na performanse poduzeća, no utvrđu- } \\
\text { ju povezanost outsourcinga sa strategijom poduzeća i dina- } \\
\text { mičnim okruženjem u predviđanju poslovnih rezultata; kori- } \\
\text { sti od outsourcinga mogu se ostvariti u potpunosti od strane } \\
\text { poduzeća koja se bave upravljanjem troškova i inovativnim } \\
\text { strategijama diferencijacije, a poduzeća koja posluju u relativ- } \\
\text { no stabilnim okruženjima mogu povećati svoje performanse } \\
\text { kroz outsourcing. }\end{array}$ \\
\hline $\begin{array}{l}\text { Isaksson, A., } \\
\text { \& Lantz, B. } \\
\text { (2015) }\end{array}$ & $\begin{array}{l}\text { Regresijska analiza provedena na temelju podataka prikuplje- } \\
\text { nih od } 400 \text { malih }(<50 \text { zaposlenika) proizvodnih poduzeća } \\
\text { u Švedskoj, nije pokazala značajan odnos između temeljnih } \\
\text { aktivnosti/djelatnosti za koje poduzeće koristi outsourcing } \\
\text { (back office djelatnosti, osnovne djelatnosti, računovodstve- } \\
\text { nu djelatnost i pomoćne djelatnosti) i financijske performanse } \\
\text { poduzeća. }\end{array}$ \\
\hline
\end{tabular}

\section{Izvor: Sistematizacija i izrada autora}

S ciljem prikaza moguće primjene TCE teorije u kontekstu outsourcinga računovodstva, u nastavku rada prikazuje se istraživački model autora Kamyabi i Devi (2011a) koji predstavlja polazište ovom radu, a ujedno i daljnjim istraživanjima navedene tematike. Model je konstruiran u skladu s TCE teorijom te je njime ispitan odnos između postavljenih nezavisnih i zavisnih varijabli, posredstvom jedne medijatorske varijable ${ }^{1}$. Autori su navedeni model koristili u više pojedinačnih radova, mijenjajući pojedine varijable, no za potrebe ovog rada, odabrane

1 Varijabla koja ukazuje na prirodu veze između zavisne i nezavisne varijable i pruža dodatne informacije temeljem čega je objašnjenje odnosa zavisnih i nezavisnih varijabli potpunije i kvalitetnije. 
su one koje su prvotno definirane kao ključne dimenzije, odnosno čimbenici TCE teorije. Uz modelom definirane varijable u nastavku, moguće je ispitivati utjecaj i brojnih drugih, kao primjerice: povjerenje u eksternog računovođu, veličinu poduzeća, kompetencije menadžera/vlasnika, snagu konkurencije. Model proučava dvostruki utjecaj, prvotno ključnih čimbenika na odluku o primjeni outsourcinga računovodstvene funkcije i razinu njegove upotrebe u poslovanju, a zatim utjecaj outsourcinga računovodstvene funkcije na uspješnost poduzeća. Ovim se pristupom nastoji prikazati cjelokupan model te time ukazati na mogućnost primjene TCE teorije u kontekstu outsourcinga računovodstva i u poduzećima $u$ RH.

Slika 1. Teorijski model istraživanja

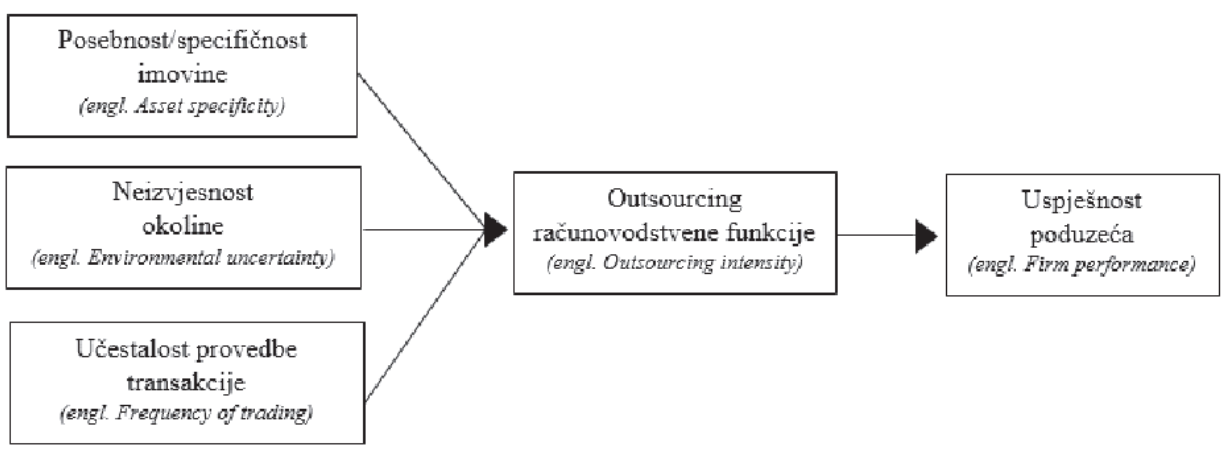

Izvor: izrada i prilagodba autora prema Kamyabi i Devi (2011a, 2011b, 2011c, 2011d, 2011e), Kamyabi (2012), Everaert, Sarens i Rommel (2010).

Zavisna varijabla modela uspješnost je poduzeća (engl. Firm Performance) (Kamyabi i Devi, 2011a, 2011b, 2011d; Kamyabi, 2012.; Adeyemi, Obah i Udofiaa, 2015.), varijabla outsourcing računovodstvene funkcije koja podrazumijeva razinu upotrebe outsourcinga (engl. Outsourcing Intensity) (Kamyabi i Devi, 2011a, 2011b, 2011c; Everaert, Sarens i Rommel, 2006., 2010.; Kamyabi, 2012..; Hafeez i Andersen, 2014.; Adeyemi, Obah i Udofiaa, 2015.) predstavlja medijatorsku varijablu, a kao nezavisne varijable postavljaju se ključne tri dimenzije TCE teorije, a to su: neizvjesnost okoline (engl. Environmental Uncertainty) (Everaert, Sarens i Rommel, 2010.; Kamyabi i Devi, 2011b, 2011e), učestalost provedbe transakcije (engl. Frequency of trading) (Kamyabi i Devi, 2011b; Everaert, Sarens i Rommel, 2006., 2010.; Hafeez i Andersen, 2014.). i posebnost, odnosno specifičnost dobra/imovine (engl. Asset Specificity) (Kamyabi i Devi, 2011a, 2011b, 2011c, 2011e; Everaert, Sarens i Rommel, 2006., 2010.; Hafeez i Andersen, 2014.). Autori Kamyabi i Devi (2011a, 247) varijablu uspješnost poduzeća mjere izražavanjem razine važnosti ispitanicima u pogledu financijskih i nefinancijskih ciljeva navedenih u nastavku, gdje 1 označava da određeni cilj uopće nije važan, a stupanj 5 označava iznimno važan cilj. Također, ispitanici 
izražavaju i razinu zadovoljstva pojedinim ciljevima uspješnosti u prethodnim poslovnim godinama. Navedeno je mjereno Likertovom skalom stupnjeva od 1 - 5, gdje je 1 ocjena nezadovoljstva pojedinim pokazateljem uspješnosti, a 5 visoka razina zadovoljstva istim. (Ne)financijski ciljevi uspješnosti poslovanja jesu: profitabilnost, rast prodaje, povrat na imovinu (ROA), novčani tijek, neovisnost/samostalnost, sigurnost posla. Pod varijablom outsourcing računovodstvene funkcije misli se na razinu upotrebe outsourcinga za određeni računovodstveni posao i funkciju, odnosno u kojoj se mjeri računovodstveni posao izdvaja i izvršava izvan poduzeća. Kamyabi (2011a, 2011b, 2011c, 2012) definira računovodstvene poslove za koje se želi ispitati i analizirati jesu li i u kojoj mjeri izdvojeni iz poduzeća i obavljani eksterno - izvan poduzeća od strane računovodstvenih servisa: knjigovodstvo, sastavljanje financijskih izvještaja, obračun plaća, budžetiranje/predviđanje i prognoziranje, analiza profitabilnosti kupaca, određivanje cijena, financijsko planiranje, usluge financijskog upravljanja, sustav interne kontrole. Razina u kojoj je određeni računovodstveni posao izdvojen i izvršavan eksterno ispituje se Likertovom skalom, stupnjevima od 1 do 5, gdje stupanj 1 označava kako se određena računovodstvena usluga uopće ne izdvaja, a stupanj 5 kako je računovodstvena usluga u potpunosti izdvojena i izvršavana izvan poduzeća. Što se tiče varijable neizvjesnosti okoline, u skladu s Everaert, Sarens i Rommel (2010.) i Lamminmaki (2007.), autori Kamyabi (2011b) od ispitanika prvo traže izražavanje u kojoj mjeri opterećenje računovodstvenih funkcija i poslova može varirati u njihovom poduzeću. Prema TCE teoriji, ukoliko tvrtke mogu pravilno predvidjeti i organizirati opterećenje vezano za računovodstvene poslove, i ukoliko je ono stabilno, troškovi transakcija su niski i za te će poslove poduzeća koristiti outsourcing. Nasuprot tome, niska predvidljivost i stabilnost radnog opterećenja povezanih s računovodstvenom funkcijom rezultira visokim troškovima transakcije, a TCE pretpostavlja da u velikoj neizvjesnosti tvrtke preferiraju svoje računovodstvene funkcije obavljati interno, vjerujući da mogu brže odgovoriti tržištu od eksternih (profesionalnih) računovođa (Kamyabi i Devi, 2011b). Nadalje, ispituje se je li u prethodnoj poslovnoj godini došlo do izmjena u poslovnoj organizaciji poduzeća. Navedeno je mjereno pomoću Likertove ljestvice 7 stupnjeva (1 - potpuno neslaganje, 7 - potpuno slaganje). Varijabla učestalost provedbe transakcije (engl. Frequency of trading), pritom misleći na one računovodstvene mjeri se na dva načina (Lamminmaki, 2007). Prvo, ispituje se koliko često se svaki računovodstveni posao izvršavao tijekom prethodne godine (Lamminmaki, 2007; Everaert, Sarens i Rommel, 2010). Navedeno je definirano kategorijama dnevno, tjedno, mjesečno, tromjesečno, polugodišnje i godišnje. Drugo, od ispitanika je zatraženo navođenje ukupnog broja (količine) ulaznih i izlaznih računa koje je računovođa obrađivao za anketirano poduzeće tijekom prethodne godine u šest kategorija (od manje od 1.000 do više od 30.000) (Everaert, Sarens i Rommel, 2010). Za računanje ukupne mjere učestalosti, mjera učestalosti provedbe kombinirana je s količinom, odnosno volumenom faktura/ 
računa. Kod varijable specifičnost dobra/imovine definirane su dvije uobičajene vrste specifične imovine: fizička (materijalna) imovina, primjerice posebna oprema i strojevi i nematerijalna imovina (naglasak je na ljudskom kapitalu) pod kojom se podrazumijevaju znanja i vještine specifične za transakcije (Kamyabi i Devi, 2011a, prema: McIvor, 2009.). Specifičnost ljudske imovine obuhvaća svako jedinstveno znanje ili vještinu koju zaposlenik razvija obukom i edukacijama, a predstavlja specijalizirano znanje ili iskustvo koje nije prenosivo - znanje ili vještina se ne mogu prenijeti jer imaju ograničen značaj za druge poslovne situacije i potrebe (Kamyabi i Devi, 2011a, prema: Lamminmaki, 2007.). Nematerijalna imovina - ljudski kapital specifična je jer je nužno da računovođe posjeduju specijalizirana znanja o specifičnim karakteristikama poduzeća kako bi mogli obaviti nužnu određenu računovodstvenu funkciju (Kamyabi i Devi, 2011a, prema: Everaert, Sarens i Rommel, 2010.). U skladu s TCE teorijom, outsourcing je moguće koristiti kod transakcija s niskom razinom specifičnosti imovine, i manjom učestalošću provedbe. Računovodstvene funkcije su osobito intenzivne i mjera specifičnosti imovine temelji se prvenstveno na nematerijalnoj imovini - ljudskom kapitalu. Specifičnost imovine na ovaj su način mjerili Kamyabi i Devi (2011a), preuzevši temelj od autora Everaert, Sarens i Rommel (2010.), ispitujući koliko su fizička i ljudska imovina specifične za mala i srednja poduzeća. Slaganje s postavljenim izjavama mjereno je Likertovom ljestvicom 7 stupnjeva, a ispituje se koliko su nužne konkretne informacije o poduzeću u izvršenju redovnih računovodstvenih poslova, zatim je li način obavljanja računovodstvenih poslova jedinstven za poduzeće te bi li bilo skupo u smislu vremena i resursa prebaciti poslovanje profesionalnom računovođi. Također, ispituje se i posjedovanje računovodstvenog softvera prilagođenog poduzeću kako bi se utvrdilo koliko je fizička imovina specifične za poduzeće. Prethodni je model sumiran na temelju različitih istraživanja (Kamyabi i Devi (2011a, 2011b, 2011c, 2011d, 2011e), Kamyabi (2012.), Everaert, Sarens i Rommel (2010.) te prikazan teorijski, s ciljem isticanja i naglašavanja mogućnosti primjene istog na poduzeća u RH. Zaključci koji se mogu iznijeti sukladno proučavanjem dobivenih rezultata istraživanja provedenih na prethodno prikazani način slijede u nastavku.

Prethodno definiranim i objašnjenim varijablama, postavljenim hipotezama i provedenom regresijskom analizom, na uzorku od 658 upotrjebljivih upitnika, ispunjenih od poduzeća s brojem zaposlenih do 250 sa sjedištem u Iranu, autori Kamyabi i Devi (2011a, 2011b, 2011c, 2011d, 2011e) došli su do sljedećih zaključaka: postoji značajna povezanost i signifikantnost varijabli u modelu (pozitivno/ negativno ovisno o varijabli) s razinom upotrebe outsourcinga računovodstvene funkcije čime su pružili specifično, teorijski i empirijski utemeljeno predviđanje kako TCE čimbenici utječu na outsourcing računovodstvenih funkcija s implikacijama za teoriju i praksu. Nadalje, posredstvom varijable outsourcinga računovodstvene funkcije (misleći na razinu upotrebe istog) autori dolaze do zaključaka 
o značajnoj i pozitivnoj povezanosti s uspješnošću poduzeća, te navode da se uspješnost izravno poboljšava u mjeri u kojoj poduzeće koristi outsourcing računovodstvene aktivnosti, što postavlja temelj istraživanju u RH kako bi se donijeli konkretni zaključci za praksu outsourcinga računovodstva na poduzećima koja djeluju i rade na području RH.

\section{ZAKLJUČNA RAZMATRANJA}

Analizom dostupnih i relevantnih sekundarnih podataka, kao i uvidom u inozemnu literaturu i iskustva primjene outsourcinga, moguće je zaključiti kako su razlike između hrvatske i inozemne prakse primjene outsourcinga u poslovanju poduzeća generalno, a posebice outsourcinga računovodstvene funkcije, neupitne i evidentne. Po pitanju stanja i situacije u RH ono što se može istaknuti kao pozitivan pomak rezultati su istraživanja Cronata d.o.o. Varaždin i BNB Sklad d.o.o. Zagreb (2016.) koji ukazuju na prepoznavanje važnosti i prednosti outsourcinga te povećanje razine znanja i svijesti o samom outsourcingu. Također, anketirana poduzeća pokazuju namjeru upotrebe oustourcinga u većem obujmu, što je također dobar pokazatelj za budućnost primjene oustourcinga u RH, kao i sadašnje poznavanje koncepta outsourcinga. Ono što je pak negativno i na čemu je nužno raditi i što zapravo daje temelj daljnjim istraživanjima navedene problematike jest i dalje prisutno veliko neznanje tržišta za koje se sve usluge može koristiti outsourcing, koje su prednosti koje se njime mogu ostvariti u poslovanju i koju je razinu kvalitete danas navedena strategija u RH dostigla. Nadalje, nužno je da poduzeća koja direktno sudjeluju i surađuju u konceptu outsourcinga slušaju i uvažavaju u potpunosti „,suprotnu“ stranu, odnosno teže i njeguju partnerski odnos. Stoga, budućim istraživanjima promatrane tematike na području $\mathrm{RH}$ višestruko će se doprinijeti, prvenstveno jer istraživanja ovakve vrste i predmeta još nisu provedena na području RH te bilo kakvi podatci o stupnju primjene outsourcinga računovodstvene funkcije u poslovanju poduzeća $u$ RH, kao i utjecaju istog na uspješnost poslovanja ne postoje. Doprinos se ogleda u promatranju outsourcinga računovodstvene funkcije sa dvije različite strane te dobivanje informacija i podataka sa različitih, no međusobno povezanih i uključenih strana u samom outsourcingu računovodstva - primatelja (poduzeća) i pružatelja (računovodstveni servisi), čime će biti moguće objediniti oprečne podatke kojih međusobno uključene strane nisu svjesne te otvoriti mogućnosti za poboljšanje njihova odnosa, kao i dati preporuke objema stranama za uspješniju suradnju u budućnosti. Identifikacijom ključnih varijabli za obje strane u outsourcingu moći će se ukazati i utjecati na razlike u percepciji i boljem shvaćaju ,druge“ strane, njenih potreba, zadovoljstva, očekivanja i problema, a u konačnici i kvalitete dobivenih informacija od suprotne strane u smislu pomoći pri poslovnom odlučivanju. Provedba empirijskog istraživanja na području RH o učincima outsourcinga računovodstvene 
funkcije na poslovanje u cjelini imati će veliko praktično značenje jer o istom ne postoje saznanja i zaključci, a poduzećima koja razmišljaju o, upravo uvode ili se tek spremaju na uvođenje koncepta poslovanja outsourcinga takve će informacije biti neprocjenjive i ključne u odluci o primjeni outsourcinga u poslovanju.

\section{LITERATURA}

1. Adeyemi, S. B., Obah, S., \& Udofiaa, I. E. (2015.). Determinants of demand and supply of accounting and audit services in SMEs: Evidence from Nigeria. Accounting and Management Information Systems, 14(3), str. 546-574.

2. Anadachee, K. (2012.). Examination of outsourcing in an accounting firm: a shift in the unit analysis: ethnographic study of blocks to knowledge sharing. PhD Thesis. University of London.

3. Arnold, U. (2000.). New dimensions of outsourcing: a combination of transaction cost economics and the core competencies concept. European Journal of Purchasing \& Supply Management, 6(1), str. 23-29.

4. Bahtijarević-Šiber, F., \& Sikavica, P. (2001.). Leksikon menadžmenta. Zagreb: Masmedia.

5. Brkić, A. (2013.). Outsourcing IT projekata u RH. Diplomski rad. Split: Ekonomski fakultet u Splitu.

6. Coase, R. H. (1937.). The nature of the firm. Economica, New Series, 4(16), str. 386-405.

7. Cronata d.o.o. i BNB Sklad d.o.o. (2016.). Outsourcing u službi razvoja poslovanja poduzeća u Republici Hrvatskoj. Online istraživački projekt, anketni upitnik dostupan na: https://goo.gl/forms/HZwwVyQTo5hK9BV92.

8. Dražić Lutilsky, I., Dragija, M., \& Krnjić A. (2015.). Infuence of outsourcing on the cost management. U: Zbornik radova 4. međunarodnog znanstvenog simpozija Gospodarstvo istočne Hrvatske - vizija i razvoj. Osijek, 21-23.05.2015., Osijek: Ekonomski fakultet u Osijeku, str. 281-294.

9. Dunković, D. (2001.). The Economics of Transaction Cost: a Development of the Modern Partnership Framework. Ekonomski vjesnik, 14(1/2), str. 101-129.

10. Espiritu, R.T., Jr. (2008.). Measures of alliance success: a study of outsourcing professionals in the United States. PhD Thesis. University of Phoenix.

11. Everaert, P., Sarens, G., \& Rommel, J. (2006.). Outsourcing of accounting tasks in SMEs: An extended TCE model. Working Paper No. 2004/403, Univ. Gent. Kuiperskaai, Belgium. 
12. Everaert, P., Sarens, G., \& Rommel, J. (2010.). Using Transaction Cost Economics to explain outsourcing of accounting. Small Business Economics, 35(1), str. 93-112.

13. Gilley, K. M., \& Rasheed, A. (2000.). Making more by doing less: an analysis of outsourcing and its effects on firm performance. Journal of management, 26(4), str. 763-790.

14. Hafeez, A., \& Andersen, O. (2014.). Factors Influencing Accounting Outsourcing Practices among SMEs in Pakistan Context: Transaction Cost Economics (TCE) and Resource-Based Views (RBV) Prospective. International Journal of Business and Management; 9(7), str. 19-32.

15. Hamzah, N., Aman, A., Maelah, R., Auzair, S. M., \& Amiruddin, R. (2010.). Outsourcing decision processes: A case study of a Malaysian firm. African Journal of Business Management, 4(15), str. 3307-3314.

16. Hayes, N. (1999.). Outsourcing of typical accounting functions: impact on the accounting services industry. Master thesis. Victoria University of Technology, Australia.

17. Isaksson, A., \& Lantz, B. (2015.). Outsourcing Strategies and Their Impact on Financial Performance in Small Manufacturing Firms in Sweden. The International Journal of Business and Finance Research, 9(4), str. 11-20.

18. Kamyabi, Y., \& Devi, S. (2011a). The Impact of Accounting Outsourcing on Iranian SME Performance: Transaction Cost Economics and Resource-Based Perspectives. World Applied Sciences Journal, 15(2), str. 244-252.

19. Kamyabi, Y., \& Devi, S. (2011b). Outsourcing of accounting functions in the context of SMEs in emerging economies: Transaction cost economics perspective. Australian Journal of Basic and Applied Sciences, 5(11), str. 1696-1703.

20. Kamyabi, Y., \& Devi, S. (2011c). An empirical investigation of accounting outsourcing in Iranian SMEs: transaction cost economics and resource-based views. International Journal of Business and Management, 6(3), str. 81-94.

21. Kamyabi, Y., \& Devi, S. (2011d). Accounting outsourcing and firm performance in Iranian SMEs. International Journal of Economics and Finance, 3(4), str. 181-192.

22. Kamyabi, Y., \& Devi, S. (2011e). Using Transaction Cost Economics and Resource-Based views in Management Accounting Outsourcing: An empirical study of Iranian SMEs. Middle East Journal of Scientific Research, 10(1), str. 87-98.

23. Kamyabi, Y. (2012.). Accounting function outsourcing among Iranian SMEs and its impact on firm performance. PhD Thesis, University of Malaya. 
24. Kolaković, M., Kovačević, B., \& Sisek, B. (2002.). Utjecaj teorija poduzeća na suvremene pristupe organizaciji poduzeća. Ekonomski pregled, 53(9-10), str. 934-956.

25. Križman Pavlović, D., \& Kalanj, I. (2008.). Uloga poslovnog pregovaranja u stjecanju konkurentske prednosti. Ekonomska istraživanja, 21(4), str. 62-81.

26. Krnjić, A. (2014.). Utjecaj outsourcinga na smanjenje troškova, Diplomski rad. Sveučilište u Zagrebu: Ekonomski Fakultet u Zagrebu.

27. Lamminmaki, D. (2007.). Outsourcing in Australian Hotels: A Transaction Cost Economics perspective. Journal of Hospitality \& Tourism Research, 31(1), str. 73-110.

28. Liović, D. (2016.). Outsourcing - rizična ušteda? FINIZ 2016 - Risks in Contemporary Business, Belgrade, Singidunum University, DOI: 10.15308/ finiz-2016-223-230, str. 223-230.

29. McCarthy, I., \& Anagnostou, A. (2004.). The impact of outsourcing on the transaction costs and boundaries of manufacturing. International journal of production economics, 88(1), str. 61-71.

30. McIvor, R. (2009.). How the transaction cost and resource-based theories of the firm inform outsourcing evaluation. Journal of operations management, 27(1), str. 45-63.

31. Mlikotin Tomić, D., \& Šega, A. (2006.). Ekonomska analiza prava: razvoj i aktualnost. Zbornik Ekonomskog fakulteta u Zagrebu, 4(1), str. 365-376.

32. Narodne novine (2015.). Zakon o računovodstvu, NN broj 78/15, 134/15, 120/16, Zagreb.

33. Neves, L. W. D. A., Hamacher, S., \& Scavarda, L. F. (2014.). Outsourcing from the perspectives of TCE and RBV: a multiple case study. Production, 24(3), str. 687-699.

34. Parlov, I. (2004.). The influence of outsourcing on achieving business goals in large Croatian companies. Management, 9(1), str. 47-72., Split: Sveučilište u Splitu, Ekonomski fakultet.

35. Pavić, M. (2009.). Uloga outsourcinga u povećanju konkurentnosti velikih hrvatskih poduzeća na međunarodnom tržištu. Zagreb: Poslovna izvrsnost.

36. Šarić, M. (2012.). Eksternalizacija kao model restrukturiranja poduzeća. [Elektronska verzija]. Tranzicija, 14(29), str. 122-131. Retrieved August 19, 2016., http://hrcak.srce.hr/86075.

37. Vučur, G. (2016.). Utjecaj outsourcinga na profitabilnost hotelskih poduzeća. Ekonomska misao i praksa, 25(1), str. 283-300. 
Dina Liović, M.A., Ph.D. candidate

Faculty of Economics, Josip Juraj Strossmayer University of Osijek, Osijek, Republic of Croatia

dinali@efos.hr

\title{
Blaženka Hadrović Zekić, Ph.D.
}

Faculty of Economics, Josip Juraj Strossmayer University of Osijek, Osijek, Republic of Croatia

hadrovic@efos.hr

\section{Ivana Dražić Lutilsky, Ph.D.}

Faculty of Economics and Business, University of Zagreb, Republic of Croatia idrazic@efzg.hr

\section{OUTSOURCING THE ACCOUNTING FUNCTION - THE COST MANAGEMENT STRATEGY WITHIN TRANSACTION COSTS ECONOMICS}

Review

\begin{abstract}
Transaction cost economics (TCE), an interdisciplinary approach that explains the emergence and operation of a company, can be diversely applied in everyday business, e.g. in making business decisions or in analyzing the management structure of the relationship buyer - supplier. This approach considers total operational costs, especially the costs of contracting and negotiation, and also the management process which provides a definition of company boundaries. This explains why some companies perform certain tasks on their own, while others contract other companies who are more competent in a particular field. In this context, it is also possible to apply transaction cost economics to outsourcing, which is a cost management strategy used to deal with certain non-core business activities. In this way, it is possible to get high-quality services at lower costs, while the company can focus on its core business. The core business function studied in this paper is the accounting function, which plays a significant role in any company, regardless of its legal form, size or structure.
\end{abstract}

The primary aim of the paper is to relate the theoretical framework to practice and to indicate how the model could be used in business operations. The paper provides a detailed review of previous research and results obtained through the research regarding outsourcing of the accounting function within the transaction costs economics. In the literature review there is a special emphasis on the context 
of determinants and factors that lead a company to decide to outsource their accounting functions. The impact of such outsourcing on company performance is analyzed using the transaction costs economics. This seems to be necessary given that there is no carried out research within this context in the Republic of Croatia, but also taking into account the (still) numerous concerns and controversies surrounding the concept of outsourcing.

Keywords: transaction cost economics, outsourcing, accounting function, accounting service

JEL: D23, M41, M55 